\title{
HOLOCENE PALAEOENVIRONMENTAL EVOLUTION OF THE PAMPA COASTAL PLAIN (ARGENTINA) BASED ON CALCAREOUS MICROFOSSILS
}

\author{
MELINA MARQUEZ, LAURA FERRERO \\ Instituto de Geología de Costas y del Cuaternario, Universidad Nacional de Mar del Plata, IIMyC-CONICET, Funes 3350, \\ Mar del Plata, CC722, Buenos Aires, Argentina.mmarquez@mdp.edu.ar,marmart@mdp.edu.ar \\ GABRIELA CATALINA CUSMINSKY \\ Centro Regional Universitario Bariloche, Universidad Nacional del Comahue, INIBIOMA-CONICET, Quintral 1250, \\ San Carlos de Bariloche, 8400, Río Negro, Argentina.gcusminsky@gmail.com
}

\begin{abstract}
In the present contribution, we studied assemblages of benthic foraminifers, ostracods and charophytes in a Holocene outcrop in the southeast of the La Pampa coastal plain in Argentina. The main species recorded were Spirillina sp. A, Buccella peruviana, Ammonia parkinsoniana, A. tepida, Elphidium margaritaceum and E. gunteri among foraminifers, Limnocythere cusminskyae and Cyprideis salebrosa among ostracods. These species allowed to determine restricted environments characterized by significant changes in salinity. Qualitative and quantitative studies conducted on the faunal content in the outcrop allowed to identify four environments closely linked to the sea-level changes occurred during the Holocene. In a first stage, between 7500-7200 and 6300-6200 cal yr BP represent the development of a non-marine environment. Around 6300-6200 cal yr BP this environment change to brackish-estuarine with moderate energy. Sometime before $c$. 6000-5700 cal yr BP a clear-water lagoon, probably oligohaline, with abundant submerged vegetation is inferred. In a final stage, from 2300-2000 to 2000-1700 cal yr BP, a continental environment not influenced by the proximity of the sea was established. The new calcareous microfossils evidences and the new chronologies provided by this work, allowed us to adjust the moment of the maximum sea level rise during the Holocene transgression and contribute to a better knowledge of the evolution of coastal paleoenvironments in relation to sea level changes.
\end{abstract}

Key words: La Pampa coastal plain, paleoenvironments, mid- to late Holocene, sea level changes, calcareous microfossils, Argentina.

RESUMO - Na presente contribuição foram estudadas assembleias de foraminíferos bentônicos, ostracodes e carófitas num afloramento localizado a sudeste da planície costeira de La Pampa, Argentina. As principais espécies registradas foram Spirillina sp. A, Buccella peruviana, Ammonia parkinsoniana, A. tepida, Elphidium margaritaceum e E. gunteri entre os foraminíferos, Limnocythere cusminskyae e Cyprideis salebrosa entre os ostracodes. Estas espécies permitiram determinar ambientes restritos, caracterizados por alterações significativas na salinidade. Estudos faunísticos qualitativos e quantitativos conduziram à identificação de quatro ambientes estreitamente relacionados às mudanças no nível do mar que ocorreram durante o Holoceno. No primeiro estágio, entre 7500-7200 e 6300-6200 cal. anos AP, foi identificado o desenvolvimento de um ambiente não marinho. Em torno de 6300-6200 cal. anos AP o ambiente se transforma num estuário salobro com níveis moderados de energia. Algum tempo antes $c$. 6000-5700 cal. anos AP desenvolveu-se um ambiente lagunar de águas claras, provavelmente oligohalino, com abundante vegetação submersa. Em um estágio final, entre 2300-2000 e 2000-1700 cal. anos AP, estabeleceu-se um ambiente continental sem influencia marinha. Novas evidências trazidas pelos microfósseis calcários e as novas cronologias fornecidas por este estudo, permitiu ajustar o momento de máxima elevação do nível do mar durante a transgressão holocênica e contribuir para um melhor conhecimento da evolução dos paleoambientais costeiros em relação às alterações do nível do mar.

Palavras-chave: planície costeira de La Pampa, paleoambientes, Holoceno médio a tardio, mudanças do nível do mar, microfósseis calcários, Argentina. 


\section{INTRODUCTION}

The South American Atlantic coast has been extensively affected by the sea-level fluctuations that followed the Last Glacial Maximum. After this maximum, the sea level rose rapidly, exceeding the modern level between 9000 and 7000 yr BP in Tierra del Fuego, between 6500 and 6000 yr BP along the Pampa plain of Argentina and at $5500 \mathrm{yr}$ BP in Brazil (Isla, 1989). In the Pampa coastal plain, several authors have proposed different sea level curves that record the relative level of the sea during the maximum transgression. In the Río de la Plata River (northeast of the Pampa coastal plain), the relative level of the sea about $6000 \mathrm{yr}$ BP was $6.5 \mathrm{~m}$ above the present one (Aguirre \& Whatley, 1995; Cavallotto et al., 2004; Violante \& Parker, 2004). In Mar Chiquita (southeast of the Pampa coastal plain), the maximum sea level around $6000-5000 \mathrm{yr}$ BP has been proposed to be about 2-2.5 $\mathrm{m}$ above the present one (Schnack et al.; 1982; Isla, 1989). In the Bahía Blanca estuary (southwest of the Pampa coastal plain), the sea level $6000 \mathrm{yr}$ BP was between 5 and $6 \mathrm{~m}$ above the present one (González, 1984, 1989; Gómez \& Perillo, 1995). All these curves later show a regressive trend characterized by a stepped sea-level fall to the present position (Vilanova et al., 2006).

The Holocene marine fluctuations of the Pampa plain allowed large sectors to be affected by processes generated by changes in coastlines, giving rise to coastal environments associated with coastal barriers, beach ridges, coastal lakes and lagoons (Violante et al., 2001; Schnack et al., 2005; Laprida et al., 2007). In order to refine the interpretations of the evolution of these environments, several studies using indicators for different groups of microfossils, such as pollen, diatoms, foraminifers, ostracods and nanofossils have been carried out (Ferrero, 1996, 2006, 2009; Stutz et al., 1999, 2005; Espinosa, 2001; Espinosa et al., 2003; Prieto et al., 2004; Gómez et al., 2005, 2006; Hassan et al., 2011; CalvoMarcilese et al., 2013).

Benthic foraminifera and ostracods are widely recognized as useful tools in the reconstruction of aquatic environments, being good indicators of, among others, paleosalinity, paleodepth, and other biotic and abiotic features. Foraminifera inhabits mainly marine and brackish environments while ostracods inhabits continental as well as marine and transitional water bodies, so the joint study of both is complementary and particularly useful in the reconstruction of coastal environment. Charophytes are multicelular submerged green algae, recorded as fossil mainly by their reproductive structures. They live in various types of freshwater aquatic environments, with only a few species occurring in brackish water. They are most common at the bottom of clear lakes, usually forming extensive growths (Lee, 2008). Several studies applying these groups in paleoenvironmental reconstructions have been carried out on the Pampa coastal plain (Bertels \& Martínez, 1990, 1997; Laprida \& BertelsPsotka, 2003; Fontana, 2004; Gómez et al., 2005, 2006; Laprida et al., 2007; Cusminsky et al., 2009; Ferrero, 2006, 2009; Marquez \& Ferrero, 2011; Calvo-Marcilese et al., 2011, 2013).
In this study, we recovered foraminifera, ostracods and charophyte oogonia from a Holocene sedimentary outcrop near Las Brusquitas Creek, southeast of the Pampa coastal plain. Previously, other authors have carried out studies on the sedimentology, micropaleontology, palynology, and malacology as well as isotope analysis on the same sequence (Espinosa et al., 1984; D'Antoni et al., 1985; Isla et al., 1986; Bonadonna et al., 1995; Tonni et al., 1999; Prieto et al., 2003; Vilanova et al., 2006). The aims of the present study are 1) to contribute to the knowledge of the environmental evolution of the coastline of the Pampa plain in relation to sea level changes, based on the combined study of foraminifera, ostracod and charophyte assemblages recovered from Las Brusquitas outcrop and 2) to assess the response of these assemblages to environmental changes compared with other proxies.

\section{STUDY AREA}

The province of Buenos Aires presents a very varied geomorphology. It has over $1300 \mathrm{~km}$ of a diverse coastline, including the low flood plain of the Río de la Plata Estuary, the wetlands surrounding Samborombón Bay, Bahía Blanca Estuary and Anegada Bay, succeeded by the cliffs of the Mar del Plata area (Diez et al., 2007).

The study area is located in the southeastern part of the Pampa coastal plain (Buenos Aires province) (Figure 1). Las Brusquitas outcrop ( $38^{\circ} 14^{\prime} \mathrm{S}-57^{\circ} 46.5^{\prime} \mathrm{W}$ ) has a drainage basin of $58 \mathrm{~km}^{2}$ on a lowland depression formed by a low gradient valley, which developed during the Pleistocene. The landscape, along the coastal area, is flat with a relief more pronounced eastward and originally dominated by herbaceous vegetation. The climate is temperate and humid. The air temperature ranges from 8 to $21^{\circ} \mathrm{C}$ and precipitation from 40 to $95 \mathrm{~mm} /$ month with summer months (December to February) rainier than winter months (June to August) (Isla \& Espinosa, 1998).

This area has a microtidal regime dominated by episodic storms from the south. This storm system is greater eastward and northward toward open sea conditions and a narrow continental shelf. The mean wave height is about $0.91 \mathrm{~m}$ in Mar del Plata and significantly decreases westward (Isla \& Espinosa, 1998).

\section{LAS BRUSQUITAS LB SITE PROFILE}

The material comes from a sedimentary sequence $4 \mathrm{~m}$ long from Las Brusquitas (Figure 2). Based on Prieto et al. (2003) four main stratigraphic units have been distinguished from the bottom to the top. Unit 1 consists of deposits of fine quartz sand, more or less clayey dark greenish-gray compact, passing to reddish brown silty sand, both without mollusks. Towards the top of this unit, the sequence continues with a deposit of very fine sand, reddish brown clay, rudely stratified, with intercalations of friable sand and a bank of marine mollusks which is located at $2.4 \pm 0.2 \mathrm{~m}$ asl (Espinosa et al., 1984). Unit 2 is constituted by a succession of silt, clay and 


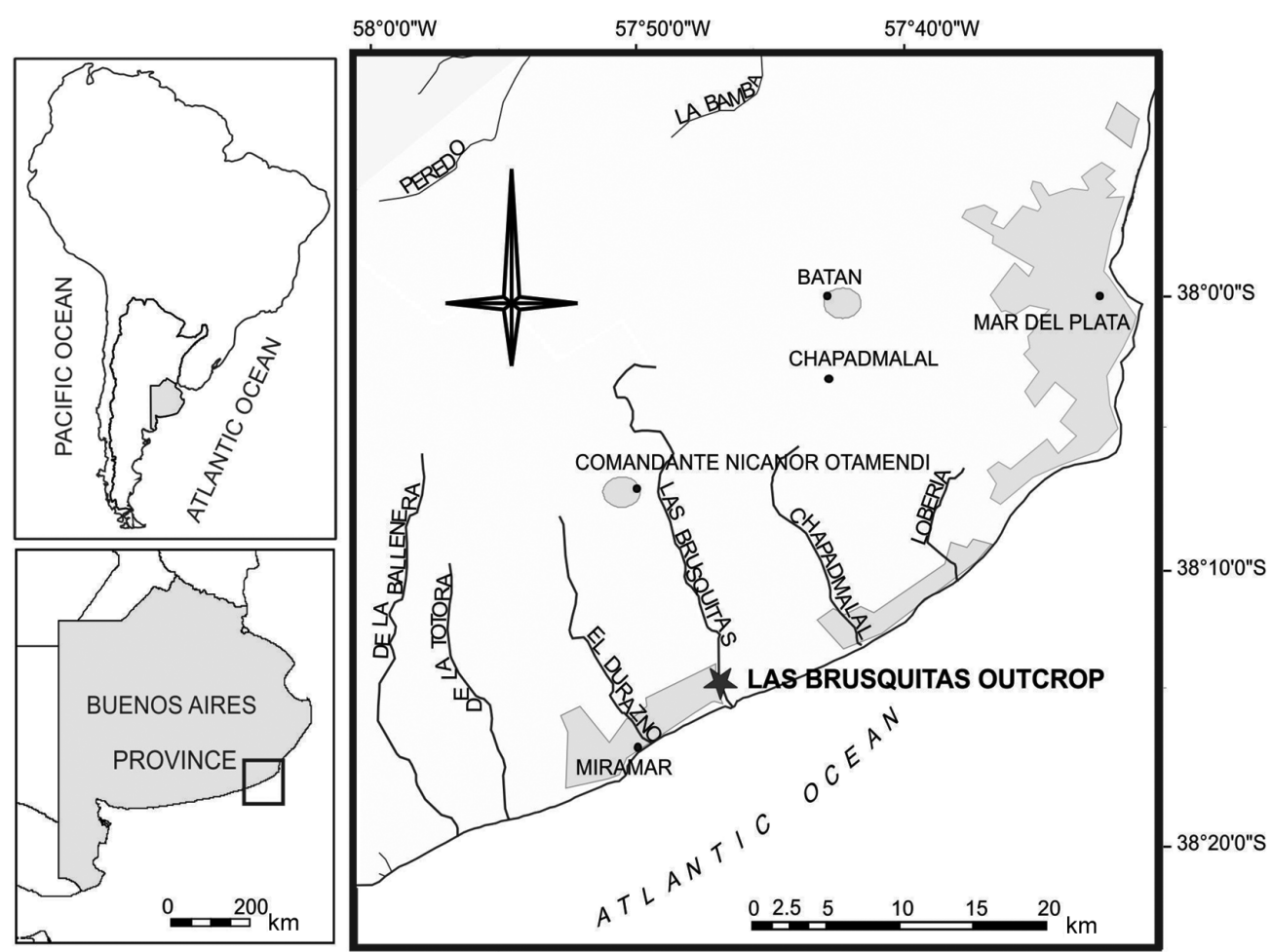

Figure 1. Location map showing the position of Las Brusquitas outcrop.

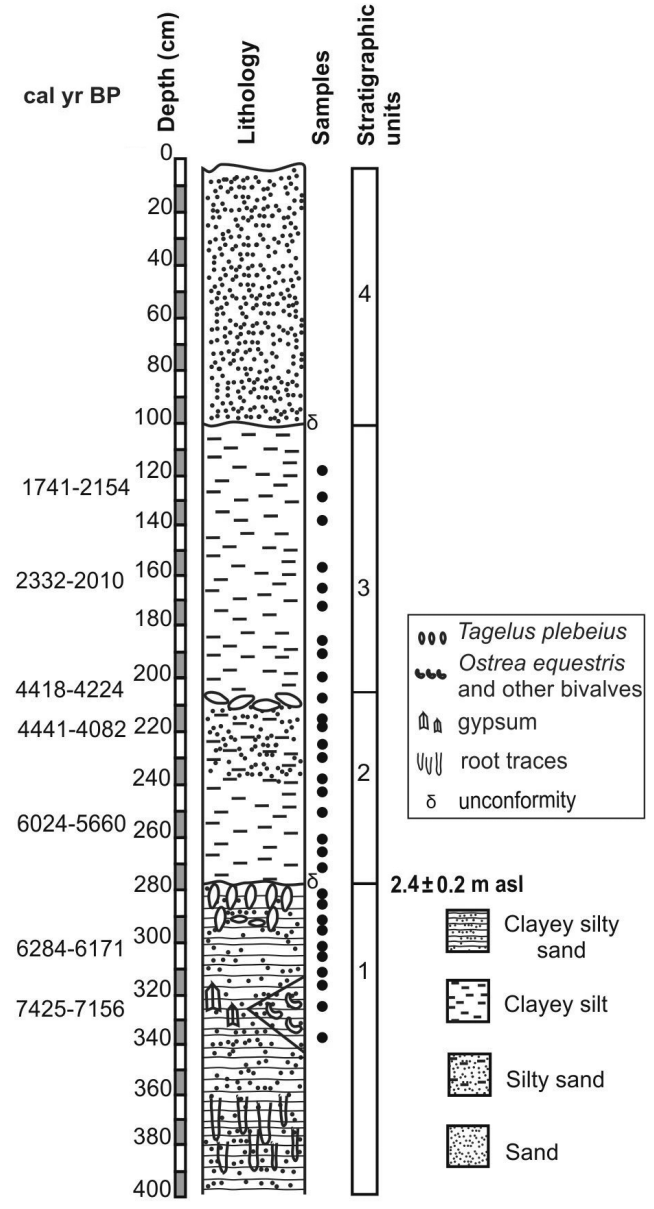

Figure 2. Sedimentary profile of Las Brusquitas outcrop (based on Vilanova et al., 2006). fine sand well stratified with several discontinuities. The basis of this level consists of intercalations of sand and mud with abundant shells: Heleobia parchappii, Heleobia australis and some Tagelus plebeius to the top. Unit 3 consists of clayey silts with coarse stratification and whole and fragmented shells of $H$. australis and $H$. parchappii, Biomphalaria peregrina, Gundlachia concentrica and fragmented remains of Mytilidae. Unit 4, which lies unconformably on Unit 3, conform by eolian sand dune deposits with evidences of pedological processes.

\section{MATERIAL AND METHODS}

The outcrop was sampled every 2,5 or $10 \mathrm{~cm}$ depending on the sedimentological features from 335 to $118 \mathrm{~cm}$. A total of 30 samples were obtained and water washed through a 63- $\mu \mathrm{m}$ mesh screen (Zonytest No. 230). Systematic analysis was based on Loeblich \& Tappan (1988) for foraminifera genera and mainly on the works by Boltovskoy (1954a, b, 1957), Boltovskoy et al. (1980), Ferrero (2006, 2009) and Calvo Marcilese (2011) for species. The quantitative values determined were total abundance, relative species abundance and diversity. To calculate total abundance, we calculated the number of specimens present in $10 \mathrm{~g}$ of gross sediment per sample. Regarding diversity, we calculated species richness $S$, Shannon-Wiener $(H)$ and Fisher's $\alpha$ indices. Taphonomic signatures, such as fragmentation, oxidation and alteration were taken into account to improve environment characterization. Ostracoda were determined based mainly on Ramírez (1967), Bertels \& Martínez (1990, 1997), Ferrero (2006), Laprida (2006), Ramón-Mercau et al. (2014). Quantitative analysis 
was performed considering adult valves. Ostracoda taxa according their saline preferences were classified in freshwater/fresh-brackish water and marine-brackish. Additionally, adult/juvenile ratio was used to improve taphonomic analysis. Charophyte gyrogonites abundances were also recorded to complete paleoenvironmental analysis.

The diagrams of relative frequencies and outcrop zoning based on foraminiferal and ostracod assemblages was done using Coniss software, included in the TILIA 1.7.16 statistic package (Grimm, 1991). The analysis considered only the species with relative abundances equal to or greater than $1 \%$ in at least two levels of the core. Standardized Euclidian distance was applied as the distance coefficient, and data transformation by standardization to mean 0 and typical deviation 1 was used. Clusters were formed according to the sum of squared error hierarchical clustering method (Grimm, 1991).

The most representative specimens were photographed with a scanning electron microscope (Jeol JSM-6460LV) and then stored at the repository of the Instituto de Geología de Costas y del Cuaternario, Universidad Nacional de Mar del Plata, Buenos Aires, under the initials CGC-F and CGC-O.

\section{Radiocarbon dates}

Radiocarbon dates and calibrations are presented in Table 1. Two new radiocarbon dates were performed for this study in order to adjust the dates made over 20 years ago (Espinosa $e t$ al., 1984; Bonadonna et al., 1995). An anomalous chronology was observed between one of the new dating (303-304 depth) and that made by Espinosa et al. (1984). Because the new dates have been made with the technique of AMS (Accelerated Mass Spectrometry) and the selected material offers greater accuracy has chosen not to consider, for discussion, the dating of Espinosa et al. (1984).

All radiocarbon dates named in this work has been calibrated with Calib 7.0.4 software (Stuiver et al., 1986) using the curve for the Southern Hemisphere (SHCal13) (Hogg et al., 2013). Correction for reservoir effect was not made because the existing database is still insufficient and the calculated values for the Argentine coast range widely from 191 to 2482 yr. probably related to differences in the contributions of carbonates dissolved in rivers and groundwater (Gómez et al., 2008).

\section{RESULTS}

Of the 30 samples observed, level 335 was sterile and no foraminifera were found in levels 310,170 and 155-118 $\mathrm{cm}$. Throughout the sediment sequence, 11 genera of benthic foraminifera were determined, distributed among 11 species and 5 species with open nomenclature (Figure 3, Appendix 1). Total abundance ranged from 7 (level $163 \mathrm{~cm}$ ) to 755 individuals (level $300 \mathrm{~cm}$ ), $S$ extend from 1 (levels 290, 249$236,216-205$, and $188-183 \mathrm{~cm}$ ) to 9 (level $280 \mathrm{~cm}$ ), values for $H$ ranged from 0 (levels 290, 241-236, 216-183 cm) to 1.6 (level $280 \mathrm{~cm}$ ), and Fisher's $\alpha$ from 0 (level 163) to 2.7 (level $280 \mathrm{~cm}$ ) (Figure 4). In general, foraminiferal fauna is composed of tests with a variable state of preservation, with a few fragmented materials. At the bottom of the section are mostly the tests having orange stain. Towards the middle part, the material presents a regular preservation state with damage not exceeding $5 \%$ of the original shell. Towards the top of the section there is less material, more fragile, often damaged but not exceeding $30 \%$ of the original test.

Ostracoda were present in almost all levels. They were very abundant mainly between levels $228 \mathrm{~cm}$ and $183 \mathrm{~cm}$ (up to 30750 valves $/ 10 \mathrm{~g}$ ), scarce in levels $315-304 \mathrm{~cm}, 294-$ $290 \mathrm{~cm}$ and $118 \mathrm{~cm}$ (less than 100 valves $/ 10 \mathrm{~g}$ ) or absent (levels $335-325 \mathrm{~cm}$ ). A total of 20 taxa were determined (Appendix 1). Most of them are well represented by adults and juvenile stages. Juveniles range from $45 \%$ to $95 \%$ of total valves along the sequence (Figure 4). Only juvenile valves of Candona sp. and Darwinula? sp. and pieces of adults and juveniles of Chlamydotheca incisa were recovered. A good preservation of valves was common, but in some levels part of the very abundant and fragile juvenile valves was fragmented. Diversity values, considering only adults, ranged from 1 (levels $188-170 \mathrm{~cm})$ to $10($ level $270 \mathrm{~cm}$ ) for $\mathrm{S}$, and from 0 (level $188-170 \mathrm{~cm}$ ) to $1.9($ level $300 \mathrm{~cm}$ ) for H. Assemblages were dominated by fresh-water/brackish ostracods; marine-brackish group was only present in a few

Table 1. Radiocarbon dates obtained from Las Brusquitas outcrop.

\begin{tabular}{|c|c|c|c|c|c|}
\hline Depth (cm) & ${ }^{14} \mathrm{C}$ yr BP & $\mathrm{Cal} \mathrm{BP} 2 \sigma$ & Material & Laboratory no. & References \\
\hline $120-125$ & $2040 \pm 80$ & $2154-1741$ & Organic matter & Beta 152124 & Prieto et al. (2003) \\
\hline $161-163$ & $2210 \pm 70$ & $2332-2010$ & Organic matter & Beta 157779 & Prieto et al. (2003) \\
\hline 228 & $3921 \pm 33$ & $4418-4224$ & Organic matter & D-AMS 010663 & This study \\
\hline $225-230$ & $3900 \pm 70$ & $4441-4082$ & Heleobia australis & LP 317 & $*$ \\
\hline $250-260$ & $5180 \pm 80$ & $6024-5660$ & Tagelus plebeius & LP 307 & $*$ \\
\hline $280-290$ & $6190 \pm 160$ & $7336-6669$ & Tagelus plebeius & AC 434 & $\begin{array}{l}\text { Espinosa et al. } \\
\text { (1984) }\end{array}$ \\
\hline $303-304$ & $5425 \pm 33$ & $6284-6171$ & Organic matter & D-AMS 010662 & This study \\
\hline $325-330$ & $6380 \pm 60$ & $7425-7156$ & Mytilus platensis & Beta 156145 & Prieto et al. (2003) \\
\hline
\end{tabular}

* (Bonnadona et al., 1995; Vilanova et al., 2006; Latyr, p.c.) 


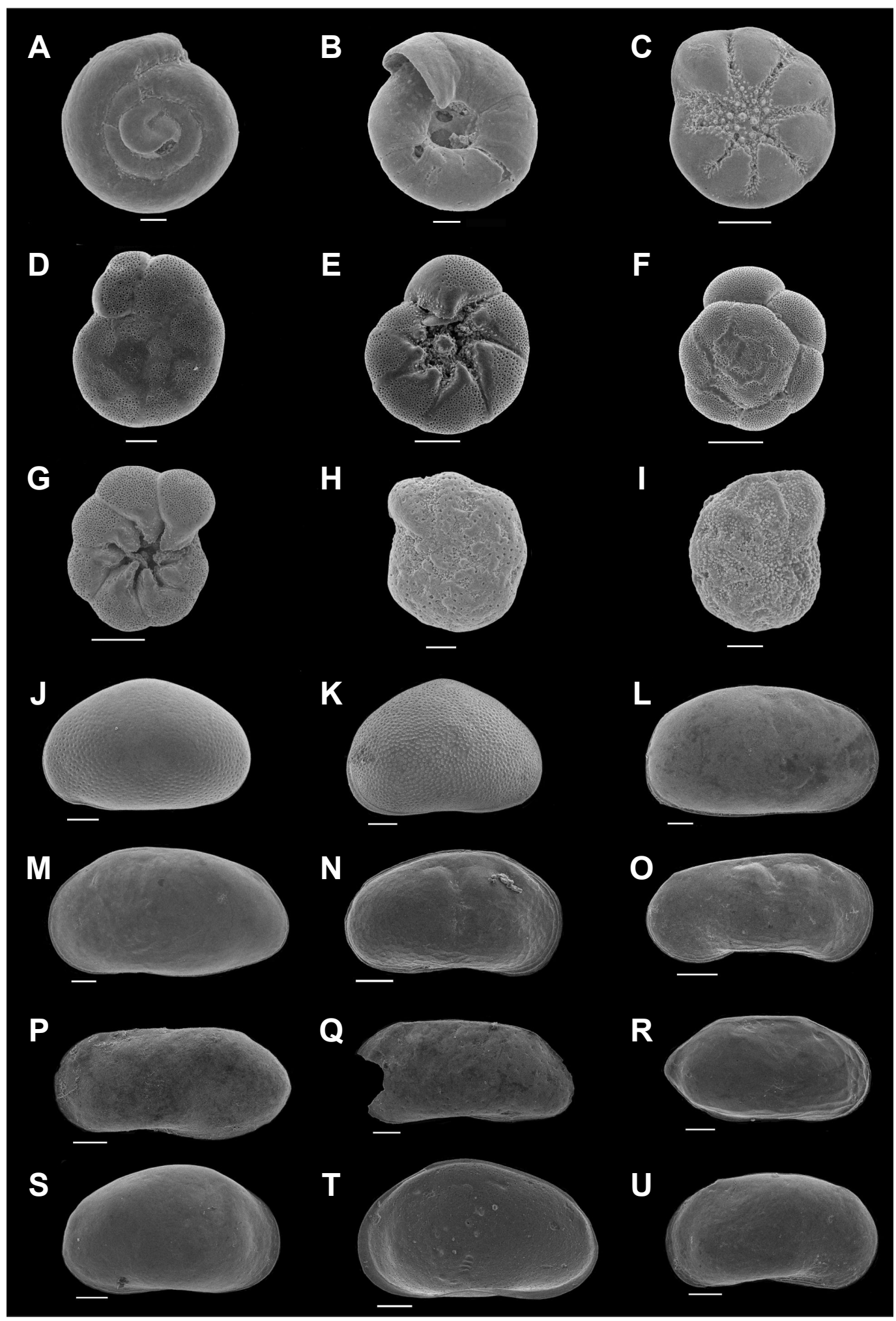

Figure 3. A, Spirillina sp. A, SV, CGC-F345, Level: $241 \mathrm{~cm}$. B, Spirillina sp. A, UV, CGC-F346, Level: $236 \mathrm{~cm}$. C, B. peruviana (d'Orbigny), UV, CGC-F347, Level: $270 \mathrm{~cm}$. D, A. parkinsoniana (d'Orbigny), SV, CGC-F348, Level: $270 \mathrm{~cm}$. E, A. parkinsoniana (d'Orbigny), UV, CGC-F349, Level: $270 \mathrm{~cm}$. F, A. tepida Cushman, SV, CGC-F350, Level: $259 \mathrm{~cm}$. G, A. tepida Cushman, UV, CGC-F351, Level: $259 \mathrm{~cm}$. H, E. gunteri Cole, CGC-F352, Level: $270 \mathrm{~cm} .$. I, E. margaritaceum Cushman, CGC-F353, Level: $270 \mathrm{~cm}$. J, Cypridopsis vidua, LV, CGC-O-130, Level: $137 \mathrm{~cm}$. K, Sarscypridopsis aculeata, C from left side, CGC-O-131, Level: $228 \mathrm{~cm}$. L, Cyprideis salebrosa, female RV, CGC-O-132, Level: $270 \mathrm{~cm}$ M, C. salebrosa, male LV, CGC-O-133, Level: 259 cm. N, Limnocythere cusminskyae, female RV, CGC-O-134/1, Level: 236 cm. O, L. cusminskyae, male RV, CGC-O-134/2, Level: $236 \mathrm{~cm}$. P, Limnocythere solum, female LV, CGC-O-135/1, Level: $270 \mathrm{~cm}$. Q, Limnocythere multiperforata, male LV, CGC-O-136, Level: $270 \mathrm{~cm}$. R, Cytherura dimorphica, female RV, CGC-O-137, Level: $223 \mathrm{~cm}$. S, Limnocytheridae gen. et sp. indet, female RV, CGC-O-138/1, Level: $249 \mathrm{~cm}$. T, Limnocytheridae gen. et sp. indet, female RV internal view, CGC-O-139, Level: $259 \mathrm{~cm}$. U, Limnocytheridae gen. et sp. indet, male LV, CGC-O-140, Level: $223 \mathrm{~cm}$. SV: spiral view; UV: umbilical view; LV: left valve; RV: right valve; C: caparace; Scale, $100 \mu \mathrm{m}$ (letters C, G, J-Q, U); $50 \mu \mathrm{m}$ (letters D-F, H-I, R); $20 \mu \mathrm{m}$ (numbers A, B). 


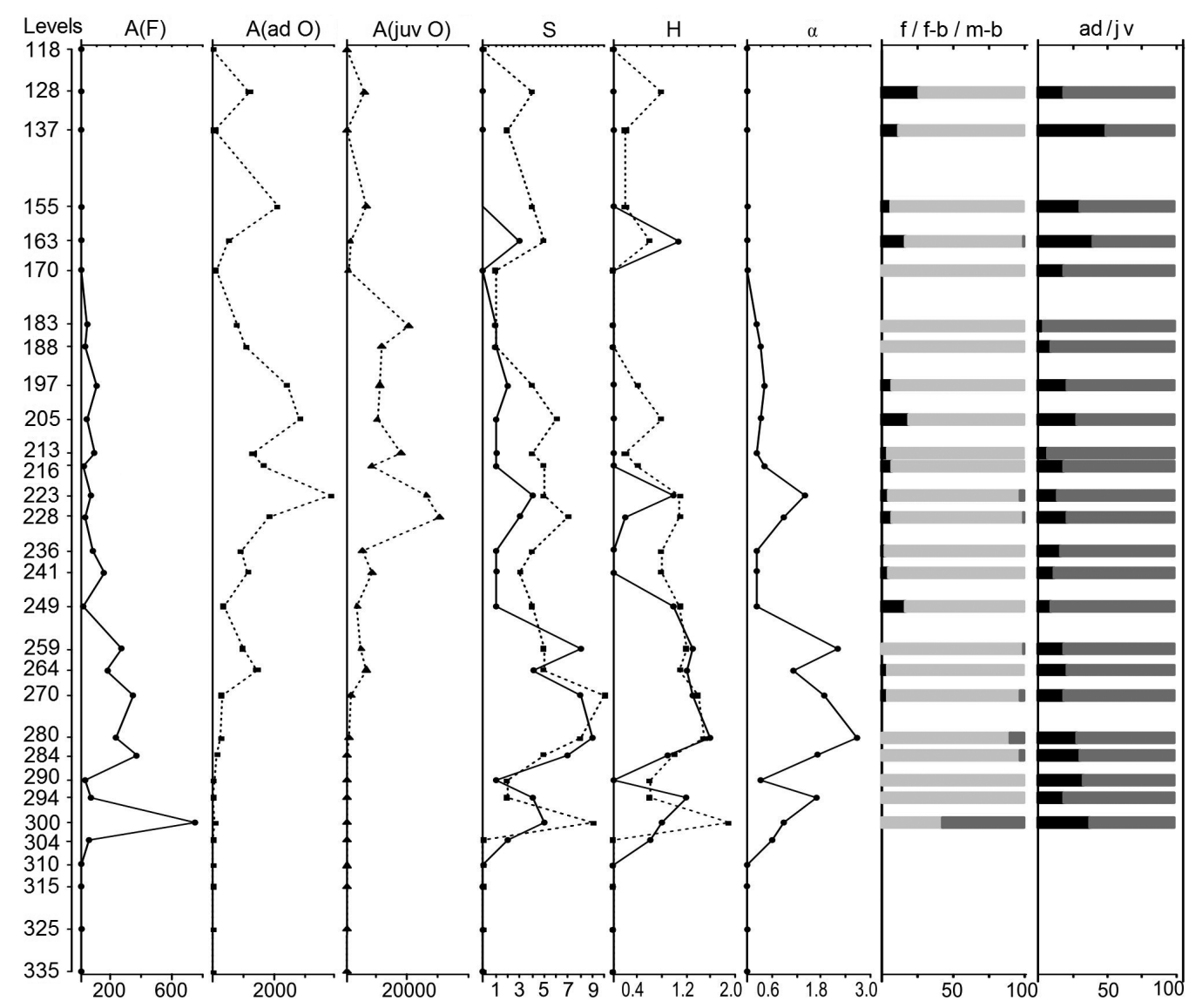

Figure 4. A: absolute abundance in $10 \mathrm{~g}$ of sediment (F: foraminifera, ad O: adult ostracod valves, juv O: juvenile ostracod valves, S: species Richness, H: Shannon-Wiener diversity index, $\alpha$ : Fisher $\alpha$ index, f/f-b/m-b: groups of species frequencies according with salinity tolerances of ostracods (f: mainly freshwater; f-b: freshwater-brackish; m-b: marine-brackish species), ad/juv: proportion of adults/juveniles of ostracods. Continuous line: foraminifera, dashed line: ostracods.

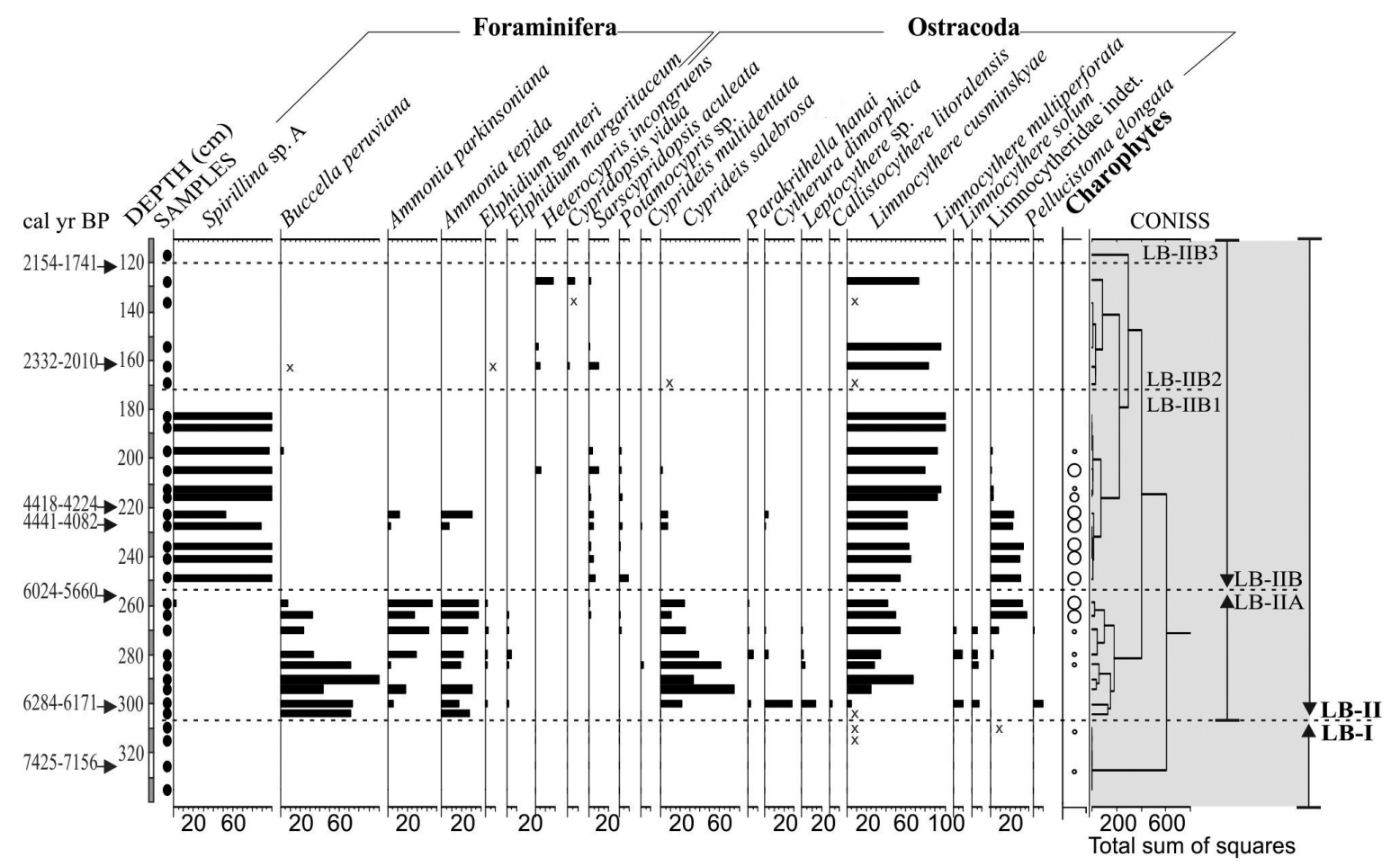

Figure 5. Stratigraphical distribution and relative abundances of foraminifera, ostracods (species with $\geq 1 \%$ ) and charophytes at Las Brusquitas outcrop (LB). It includes radiocarbon dates $\left({ }^{14} \mathrm{C}\right.$ yr BP) and the cluster analysis showing the recognized zonation. 
levels in the lower section of the sequence (levels $300 ; 284-$ $270 ; 259 ; 228-223 \mathrm{~cm}$ ).

Gyrogonites, non-calcified oogonia and vegetative remains of charophytes were common mainly from $284-197 \mathrm{~cm}$.

Cluster analysis showed two zones (Figure 5).

Zone LB-I (335-310 cm): This zone represents the lower part of the sequence and is comprised of four levels without foraminifera while a few juvenile valves of Limnocytheridae and charophyte gyrogonites were present.

Zone LB-II (310-118 cm): This zone was divided in two subzones:

Subzone LB-IIA $(310-259 \mathrm{~cm})$ :

This subzone presents the highest diversity values in forams and ostracods and also the highest foraminifera abundances of the entire sequence. Buccella peruviana was the most abundant species of the total assemblage mainly in the lower part of this subzone being more than $40 \%$ and the only species at $290 \mathrm{~cm}$ level. Ammonia tepida and Ammonia parkinsoniana were also well represented. Smaller percentages (around 1\%) of Elphidium gunteri and Elphidium margaritaceum were found. Spirillina sp. A (1\%) was present in the uppermost level of this subzone. Ostracoda assemblages were composed mainly of Cyprideis salebrosa and Limnocythere cusminskyae. The level $300 \mathrm{~cm}$ was more diverse: Limnocythere multiperforata, Limnocythere solum, Cytherura dimorphica, Pellucistoma elongata and Leptocythere sp. were also present. The increasing abundances of charophyte gyrogonites, oogonia and proportions of Limnocytheridae along with the slight decrease in $C$. salebrosa were characteristic of the upper part of this subzone. Subzone LB-IIB (259-118 cm):

This comprised of 17 levels and is characterized by the absence of $B$. peruviana, absolute dominance of $L$. cusminskyae and the scattered presence of $A$. parkinsonaiana, A. tepida and C. salebrosa. This subzone was divided in three subzones:

Subzone LB-IIB1 (259-183): This subzone presents the highest abundances of ostracods and charophytes. Among foraminifera, Spirillina sp. A was dominant (more than $55 \%$ ) in the whole subzone, while A. tepida (less than $30 \%$ ) and $A$. parkinsoniana (less than $15 \%$ ) were found only in some levels. L. cusminskyae was accompanied by Limnocytheridae gen. et sp. indet. (up to 33\%). Sarcypridopsis aculeata, Potamocypris sp. were found regularly and scarcely (less than $10 \%$ ), while C. salebrosa, Heterocypris incongruens and C. dimorphica were also present in low percentages only in few levels. Charophyte gyrogonites and non-calcified oogonia were very abundant, and parts of their vegetative structures were also found even associated to the gyrogonites.

Subzone LB-IIB2 (183-128): In this subzone only ostracods were present with very fluctuating abundances. $L$. cusminskyae was dominant while $H$. incongruens, Cypridopsis vidua, and S. aculeata were present in some levels.

Subzone LB-IIB3 $(128-118 \mathrm{~cm})$ : This subzone is comprised of one sterile level.

\section{DISCUSSION}

\section{Faunal assemblage}

Foraminiferal assemblages were represented by Buccella peruviana, Ammonia parkinsoniana and Ammonia tepida which were abundant at the lower middle part (subzone LBIIA) of the succession, accompanied by smaller percentages of Elphidium gunteri and Elphidium margaritaceum. Spirillina sp. A dominated at the upper middle part (subzone LB-IIB1), being exclusive in some levels.

According to Murray (2006), Buccella inhabits lagoons and the inner shelf $(0-100 \mathrm{~m})$ in cold temperate waters. B. peruviana is one of the most abundant and frequent species of the inner shelf and its morphotypes have been recorded in brackish water environments with variations in salinity such as the Río de la Plata River (Argentina), Lagoa dos Patos (Brazil), Chui Creek (Uruguay), and coastal environments in the south of the Pampa coastal plain (Boltovskoy, 1957; Boltovskoy \& Lena, 1974; Boltovskoy et al., 1980; Alperín et al., 2008; Cusminsky et al., 2006; Marquez et al., 2013). Recent analyses have determined that $B$. peruviana f. camps $i$ and B. peruviana f. frigida represent different developmental stages of the same species, B. peruviana (Calvo-Marcilese \& Langer, 2012).

The genus Ammonia has a wide distribution and great morphological variability, bearing high salinity ranges. Several authors agree on the existence of a single species $A$. beccarii and different forms, varieties or ecophenotypes (Schnitker, 1974; Wang \& Lutze, 1986; Walton \& Sloan, 1990). Walton \& Sloan (1990) recognized three basic forms of A. beccarii: f. beccarii, f. parkinsoniana and f. tepida. Molecular studies have suggested the separation of several of the forms attributed to A. beccarii in different species (Pawlowski et al., 1995; Hayward et al., 2004.). The specimens studied here were included in A. parkinsoniana and A. tepida (according to Calvo-Marcilese, 2011). A. beccarii f. parkinsoniana (considered in this study as A. parkinsoniana) has been recorded in environments with large variations of salinity or very low salinity (lower than $1 \%$ ) such as Quequén Grande River, Mar Chiquita Lagoon, and Río de la Plata River in Argentina, and Lagoa dos Patos in southern Brazil (Closs \& Madeira, 1968; Boltovskoy \& Boltovskoy, 1968; Boltovskoy \& Lena, 1974; Lena \& L'Hoste, 1975). A. beccarii f. tepida (considered in this study as A. tepida) is also common in estuaries, brackish and hyperhaline lagoons with sandy carbonate-rich sediments and salt marshes (Eichler et al., 1995; Debenay et al., 1998; 2001). In Araruama lagoon (Brazil), an increase in the proportion of $A$. tepida has been related to fresh water input and the enrichment in nutrients (Debenay et al., 2001). In intertidal environments of the Pampa coastal plain, A. parkinsoniana and A. tepida are distributed in a very wide range of salinities, but appear in higher proportion in low marsh and subtidal environments (Calvo-Marcilese \& Pratolongo, 2009; Marquez et al., 2013).

The genus Elphidium is widely distributed along the inner shelf of Argentina and has been recognized worldwide (Boltovskoy, 1976; Murray, 2006). E. gunteri has been cited 
for brackish environments, marshes, estuaries and coastal lagoons (Boltovskoy \& Boltovskoy, 1968; Boltovskoy, 1976; Scott et al., 1990; Cusminsky et al., 2006; Marquez et al., 2013). E. margaritaceum has been characterized by Alve \& Murray (1999) as a stenohaline species and has been found living in the Baltic Sea, at stations with $>24 \%$ o salinity. It has been cited for the Argentine continental shelf, in bays, estuaries and littoral environments (Boltovskoy, 1954b, 1957; Boltovskoy et al., 1980; Marquez et al., 2013).

Modern species of Spirillina have been reported from algal vegetation of sublittoral bank environments (Western Australia), in lagoons of Barbuda (West Indies) and in shallow waters associated with Macrocystis pyrifera holdfasts in Magellan Strait (Davies, 1970 in Reolid et al., 2008; Brasier, 1975, Hromic et al., 2004). These forms live on seaweeds, crawling around by means of attaching pseudopodia while grazing on epiphytic diatoms and other microalgae (Berthold, 1976; Kitazato, 1988 in Reolid et al., 2008). After a comprehensive review of known species of Spirillina and related genera, we think that Spirillina sp. A is a new species of this genus. It only is comparable to Spirilllina sp. A reported by Boltovskoy \& Boltovskoy (1968) in the lower section of Quequén Grande River at very low salinity values $(<1 \%)$. Due to the abundance and the particular kind of assemblages in which this species was found, a future study in order to clarify its taxonomic status will be carried out.

In this study, Spirillina sp. A has been found forming monospecific assemblage at the upper middle part (subzone LB-IIB1) of the sequence. A 'monospecific' fauna (dominance $\geq 80 \%$ ) occurs in sheltered, often brackish, intertidal or shallow-subtidal environments, never deeper than $25 \mathrm{~m}$ (Sen Gupta, 1999; Murray, 2006; Hayward, 2014). These stressed habitats may suffer: temperature extremes when the tide is out; extremes of dryness especially at higher sites that may not be inundated by the tides for several months on end; and sometimes, extremes of salinity, from weakly hyperhaline (40 psu) to hypohaline or even fresh water after heavy rain, when the tide is out (Hayward, 2014). We judge that Spirillina sp. A is species which probably inhabits stressed environments, primarily those stressed by low salinity.

Charophytes were better represented at medium levels (subzones LB-IIA and LB-IIB1) of the sequence. Most of charophytes species are limited to water bodies with clear, alkaline waters and low nutrient budget (García, 1994; Apolinarska et al., 2011). It is remarkable that Spirillina and charophytes were associated in most levels. This joint presence could allow us to infer for Spirillina also clear water preferences along with a possible epiphytic way of living.

Ostracod assemblages presented relatively low diversity. In the lower middle part (LB-IIA) of the sequence, Limnocythere cusminskyae and Cyprideis salebrosa were the main components of the assemblages. Upwards, Limnocytheridae species, in particular L. cusminskyae, were dominant. C. salebrosa is able to bear great salinity variations and is commonly associated with brackish environments, like estuaries or coastal lagoons (Ornellas \& Würdig, 1983; Dias Brito et al., 1988), but also inhabits lentic environments without marine connection (Ramírez, 1967; Laprida, 2006). L. cusminskyae lives in permanent lagoons or lotic waters (Laprida, 2006). According to Laprida (2006) and Laprida et al. (2014) this species prefers freshwater-oligohaline and highly alkaline waters, where it may be dominant, whereas D'Ambrosio (2014) considers this species (named as Limnocythere staplini) as an indicator of saline conditions taking into account that, even though it was found living in a wide salinitiy range $\left(0.2\right.$ to $\left.44.3 \mathrm{~g} \mathrm{l}^{-1}\right)$ at Llancanello basin, was dominant in the more saline biotope.

Other taxa associated to L. cusminskyae-C. salebrosa assemblage were Parakrithella hanai, Cytherura dimorphica, Leptocythere sp, Pellucistoma elongata and two other species of Limnocythere: L. multiperforata and L. solum. These last two species have been recorded in Quaternary sediments of different localities of Buenos Aires Province in association with brackish-water Ostracoda remains (Ferrero, 2006, 2009). The others are marine species but often occurring in brackish environments. $C$. dimorphica and species of Leptocythere sp. have been recorded living in Mar Chiquita coastal lagoon (p.o.) and in tidal flats of Bahía Blanca estuary (Martínez, 2005). P. elongata is a phytal species found in Río de la Plata and several littoral localities of Buenos Aires and Chubut Provinces (Whatley et al., 1997, 1998) and P. hanai was described by Hartmann (1962) for littoral environments of Chile and recorded by Whatley et al. $(1997,1998)$ in coastal environments of Argentina between $38^{\circ} \mathrm{S}$ and $42^{\circ} 47^{\prime} \mathrm{S}$.

Along the sequence, Limnocythere dominated assemblages can be divided in two types based mainly on the presence of a unidentificated species of Limnocytheridae. In the first, Limnocytheridae gen. et sp. indet. was the second component of the assemblage. This taxon has not found living but has been recorded in other Holocene sequences of the Pampas plain in paleoenvironments recognized as brackish with low salinity (Ferrero, 2006). Other components of this association were Sarscypridopsis aculeata and Potamocypris sp. S. aculeata is cosmopolitan, it mainly occur in brackishwater (oligohaline) but also lives in pure fresh-water (Meish, 2000), while Potamocypris is recognized as a freshwater genus occurring both in permanent and non-permanent waterbodies. In the second type, L. cusminskyae is accompanied by Heterocypris incongruens and Cypridopsis vidua. Both species are cosmopolitan and eurytopic, with wide tolerance ranges of $\mathrm{pH}$, temperature and salinity, preferring well oxygenated waters (Külköylüoğlu \& Vinyrad, 2000; Külköylüoğlu, 2003; Laprida, 2006; D’Ambrosio, 2014). Cusminsky et al. (2005) recorded this species in seeps, spring and creek pools and, in low frequencies, in permanent waters and also in ephemeral lakes.

The low diversity and abundance of foraminifera and the composition of foraminifera and ostracod assemblages recovered along Las Brusquitas outcrop allow us to infer the development of a brackish marginal marine environment at this locality. Brackish environments with similar diversity values have been inferred in several sites of the Pampa coastal plain (Laprida \& Bertels-Psotka, 2003; Calvo-Marcilese 
\& Pratolongo, 2009; Calvo-Marcilese et al., 2011, 2013; Marquez \& Ferrero, 2011).

Even though agglutinated foraminifera have been found in different biotopes of the east coast of South America (Lena \& L'Hoste, 1975; Boltovskoy et al., 1980; Scott et al., 1990; Calvo Marcilese \& Pratolongo, 2009), their absence is a common feature of most of the Holocene sequences studied in the same region including Las Brusquitas outcrop. This fact may be primarily caused by taphonomic processes. Microbial degradation of the organic cements is suggested by various authors as an important mechanism of agglutinated loss (Goldstein \& Watkins, 1999; Berkeley et al., 2007). However, some species relatively more robust appear to be more resistant to degradation, producing patterns of selective preservation (Goldstein \& Watkins, 1999; de Rijk \& Troelstra, 1999; Debenay et al., 2004; Hayward et al., 2004). CalvoMarcilese et al. (2013) argue that other possible reason of the absence of agglutinated fauna, along Holocene sections of Bahía Blanca estuary, may be related to their specificity to occupy niches especially within the salt marshes, considering their sampled sites as unsuitable to find such foraminifera.

The state of preservation of the shells (poor fragmented materials) and also, adult/juvenile ostracod ratios would indicate low energy environments prevailing. Oxidation processes at lower levels of the section were very clear. Oxidation of calcareous shells, in marine environments lagoon, was probably related to the presence of roots, precipitation of iron ions and a high content of organic matter (Ritter \& Erthal, 2011). In the middle and towards the top of the sequence, the state of preservation improved, evidenced by the shells without significant taphonomic signs.

\section{Paleoenvironmental evolution of Las Brusquitas Creek}

Four main paloenvironmental stages were recognized based on foraminifera, ostracod and charophyte assemblages:

Stage A (zone LB-I), deposited between 7500-7200 and $6300-6200 \mathrm{cal}$ yr BP $\left(6400{ }^{14} \mathrm{C}-5400{ }^{14} \mathrm{C}\right.$ yr BP $)$ : Foraminifera absence and the scarce presence of juveniles of L. cusminskyae, Leptocythere sp. and charophyte gyrogonites indicate a non-marine environment, probably with oligohaline water. The low concentration of microfossils could be explained by a high sedimentation rate during an early stage of the last marine transgression.

Stage B (subzone LB-IIA), deposited between 6300-6200 and $6000-5700 \mathrm{cal}$ yr BP $\left(5400{ }^{14} \mathrm{C}-5200{ }^{14} \mathrm{C}\right.$ yr BP): This stage, mainly characterized by the presence of the typical inner shelf foraminifera, B. peruviana and the euhaline ostracod, C. salebrosa corresponds to brackish-estuarine environments with moderate energy levels. Around 6300-6200 cal yr BP (5400 ${ }^{14} \mathrm{C}$ ), the more diverse Ostracoda assemblage, formed by a $60 \%$ of marine species, and the highest abundance of $B$. peruviana allow us recognized the level of major marine influence of Las Brusquitas outcrop. These interpretations are consistent with those made by other authors based on similar assemblages (Laprida et al., 2007; Cusminsky et al., 2009; Calvo-Marcilese et al., 2011; Marquez \& Ferrero, 2011). This is in accordance with previous geological and geomorphological studies, which indicate that at that time the sea rose and reached a maximum transgression between 6500 and 5000 yr BP (Isla, 1989; Fasano, 1991). At the end of this stage an increase of relative abundance of Ammonia spp. and Elphidium spp. plus a decrease in B. peruviana and C. salebrosa suggest that the environment evolves towards more restricted conditions. Assemblages formed by species of normal marine environments, such as B. peruviana, with a high content of brackish water species such as Elphidium spp. and Ammonia spp., were interpreted as a gradual sea level fall and/or coastal progradation and a change to a more estuarine condition (Laprida et al., 2007; Marquez \& Ferrero, 2011; Calvo-Marcilese et al., 2013). The final phase of stage $\mathrm{B}$ coincides with the first steps of the regressive event at $6000 \mathrm{yr}$ BP, when the sea level began to fall (Isla et al., 1996; Violante \& Cavallotto, 2004).

Stage C (LB-IIBI), deposited between 6000-5700 and 2300-2000 cal yr BP $\left(5200-2200{ }^{14} \mathrm{C}\right.$ yr BP): The absence of B. peruviana and C. salebrosa and the dominance of Spirillina sp. A and Limnocytheridae spp. indicate the evolution to more continental environments. The development of clear-water lagoon with abundant submerged vegetation may be inferred based upon the abundance of charophytes remains, not only calcified and non-calcified oogonia but also vegetative remains. The dominance of $L$. cusminskyae along with the presence of $S$. aculeata and Limnocytheridae gen. et sp. indet. may be related to oligohaline waters. L. cusminskyae dominated assemblages may indicate relatively low conductivity and also high alkaline waters. At c. 4400-4200 cal yr BP (c. $3900{ }^{14} \mathrm{C}$ yr BP), a rise in the diversity of both fauna groups as well as the presence of marine/brackish species, denote a sporadic increase of marine connection probably originated by extraordinary tides or storms.

Stage D (zone LB-IIB2), deposited between 2300-2000 and $2000-1700$ cal yr BP $\left(2200{ }^{14} \mathrm{C}-2000{ }^{14} \mathrm{C}\right.$ yr BP $)$ : the absence of foraminifera and ostracod assemblages reflects the establishment of a continental environment not influenced by the proximity of the sea. Furthermore, the dominance of L. cusminskyae together with the wide fluctuation in abundances of microfossils can indicate oscillations in water levels probably related to desiccation periods and salinity variations due to evaporation. Charophyte absence can be associated to low water levels and turbidity. The results of this stage are in accordance with a progressive evolution towards more restricted environments due to the establishment of a sand dune barrier, as proposed by several authors (Schnack et al, 1982; Fasano et al., 1982; Fasano, 1991; Violante, 1992; Violante \& Parker, 1992). Finally, after c. 2200-1700 cal yr BP $\left(2000{ }^{14} \mathrm{C}\right.$ yr BP $)$, the record was buried by dune sands partially modified by soil development.

\section{Comparison with other proxies}

Studies on pollen, diatoms, and mollusks as well as isotope analysis have been previously carried out by several authors in Las Brusquitas outcrop (Figure 6). Our results and interpretation are broadly agreed with their ones, only a few concordances, discrepancies or adjustment among the different lines of evidences are pointed out here. 


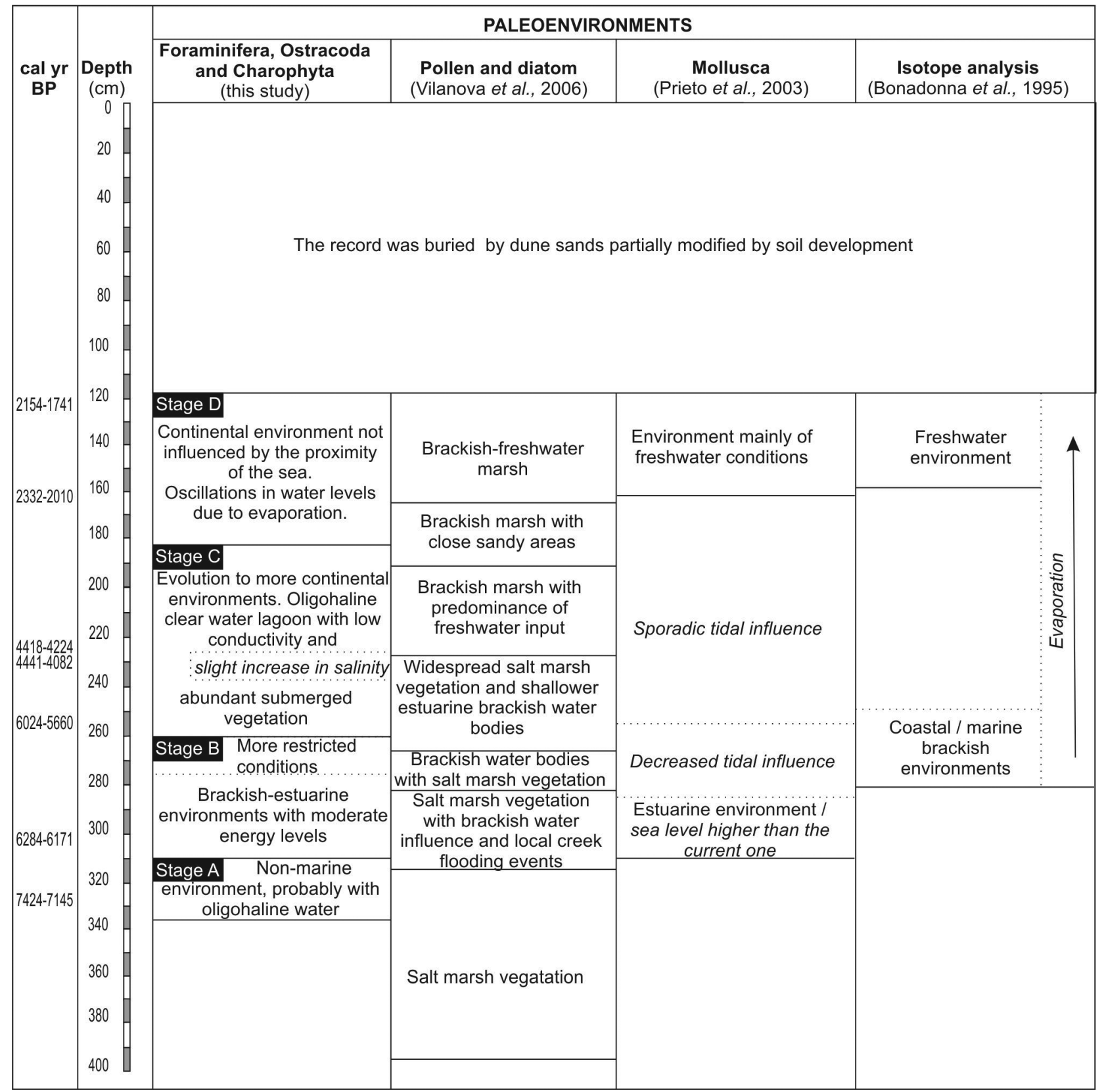

Figure 6. Summarized paleoenvironmental settings at Las Brusquitas outcrop.

From pollen and diatoms (Vilanova et al., 2006) brackish to freshwater paleoenvironments and salt to brackish marshes are inferred. On this basis we expected to find agglutinated foraminifera fauna, however this was absent. Debenay et al. (2001) were surprised to find a very low proportion of agglutinated fauna in the lagoon of Araruama (Brazil), even in organic rich sediments and lower salinity waters. The authors found no explanation for the dearth of this fauna. In Las Brusquitas outcrop we suggest two possible reasons why we didn't find agglutinated foraminifera; agglutinated loss due to taphonomic processes or that the described marshes were not so widespread or uniformly distributed, resulting in the lack of their specific niches in the sampled record.
From the mollusks (Prieto et al., 2003) and the isotope analysis $\left(\delta^{13} \mathrm{C}\right.$ and $\left.\delta^{18} \mathrm{O}\right)$ (Bonadonna et al., 1995) were also inferred brackish environments (estuarine and coastal/marine brackish, respectively) that evolve freshwater. This change is also evident from the analysis using foraminifera and ostracods combined.

At c. $4441-4082$ cal yr BP $\left(3900{ }^{14} \mathrm{C}\right.$ yr BP $)$, from the presence of a few $H$. australis and fragments of Mytilidae it was inferred that the tidal influence was still present, but limited only to extraordinary ones (Prieto et al., 2003). This ephemeral condition might be registered with the analysis of foraminifera and ostracods evidencing their sensitivity to environmental changes and the importance of carrying out paleoenvironmental studies integrating this group. 
Vilanova et al. (2006) described around to 2200-1700 cal yr BP (c. $2000{ }^{14} \mathrm{C}$ yr BP, saline condition due to desiccation or an unusually high tide range. Our results also indicate saline conditions but the absence of any marine element plus the dominance of $L$. cusminskyae make us prefer the first explanation.

\section{Holocene sea-level in the coastal region of the Pampa plain}

Paleoecological and paleoenvironmental studies from various coastal sites of the Pampa plain suggest changes in the sea level and marine influence during the Holocene. The effect of the sea-level fluctuations occurred at different times and magnitudes according to the characteristics of each basin: depth, distance from shoreline, geomorphology and freshwater input (Isla et al., 1986).

On the coast of the Pampa plain, the largest marine influence occurred, from north to south, after 7600-7500 cal yr BP in Luján River $\left(6700{ }^{14} \mathrm{C}\right.$ yr BP), prior to $6200-6000$ cal yr BP $\left(5400{ }^{14} \mathrm{C}\right.$ yr BP $)$ in the core south of Punta Rasa (Prieto et al., 2004; Laprida et al., 2007), between c. 910010200 and $8500-8000$ cal yr BP $\left(8700\right.$ and $7500{ }^{14} \mathrm{C}$ yr BP $)$ for the Mar Chiquita lagoon area, around 7750-7300 cal yr BP for Punta Hermengo (6700 ${ }^{14} \mathrm{C}$ yr BP), between $c$. 7800$7400 \mathrm{cal}$ yr BP and 6700-6400 cal yr BP (6800 and 6100 ${ }^{14} \mathrm{C}$ yr BP) for the La Ballenera Creek, and between c. 6900-
7300 and $6200-5900$ cal yr BP (6200 and $5300{ }^{14} \mathrm{C}$ yr BP) for Quequén Grande River (Ferrero, 1996; Espinosa, 2001; Espinosa et al., 2003; Hassan et al., 2011; Marquez \& Ferrero, 2011; Fayó \& Espinosa, 2014). In the Bahía Blanca estuary, the largest marine influence was recorded between $c$. 63006400 and $5900-5800 \mathrm{cal} \mathrm{yr} \mathrm{BP}\left(5600\right.$ and $5200{ }^{14} \mathrm{C}$ yr BP $)$ in Napostá Grande Stream (Calvo-Marcilese et al., 2013). On the other hand, Gómez et al. $(2005,2006)$ and Cusminsky et al. (2009) recognized negative oscillations of the Last Glacial Maximum at $6400 \mathrm{yr}$ BP, $4200 \mathrm{yr}$ BP and $2900 \mathrm{yr}$ BP during the transgressive hemicycle BP in the PS2B2 core (Figure 7).

In Las Brusquitas Creek, the maximum of marine influence reaches to $6300-6200 \mathrm{cal}$ yr BP $\left(c .5400{ }^{14} \mathrm{C}\right.$ yr BP $)$ after that age the sea began to fall. However, at $c$. 4400-4200 cal yr BP (c. $3900{ }^{14} \mathrm{C}$ yr BP), a slight increase was observed, reflecting sporadic marine influence. The environmental changes in Las Brusquitas Creek are consistent with the evolution of the coastline of the Pampa plain in relation to sea level changes.

\section{CONCLUSIONS}

From the study of calcareous proxies, can be inferred shallow and low energy marginal marine palaeoenvironments in Las Brusquitas Creek. In a first stage, between 7500-7200 and 6300-6200 cal yr BP, it could be recognized the development

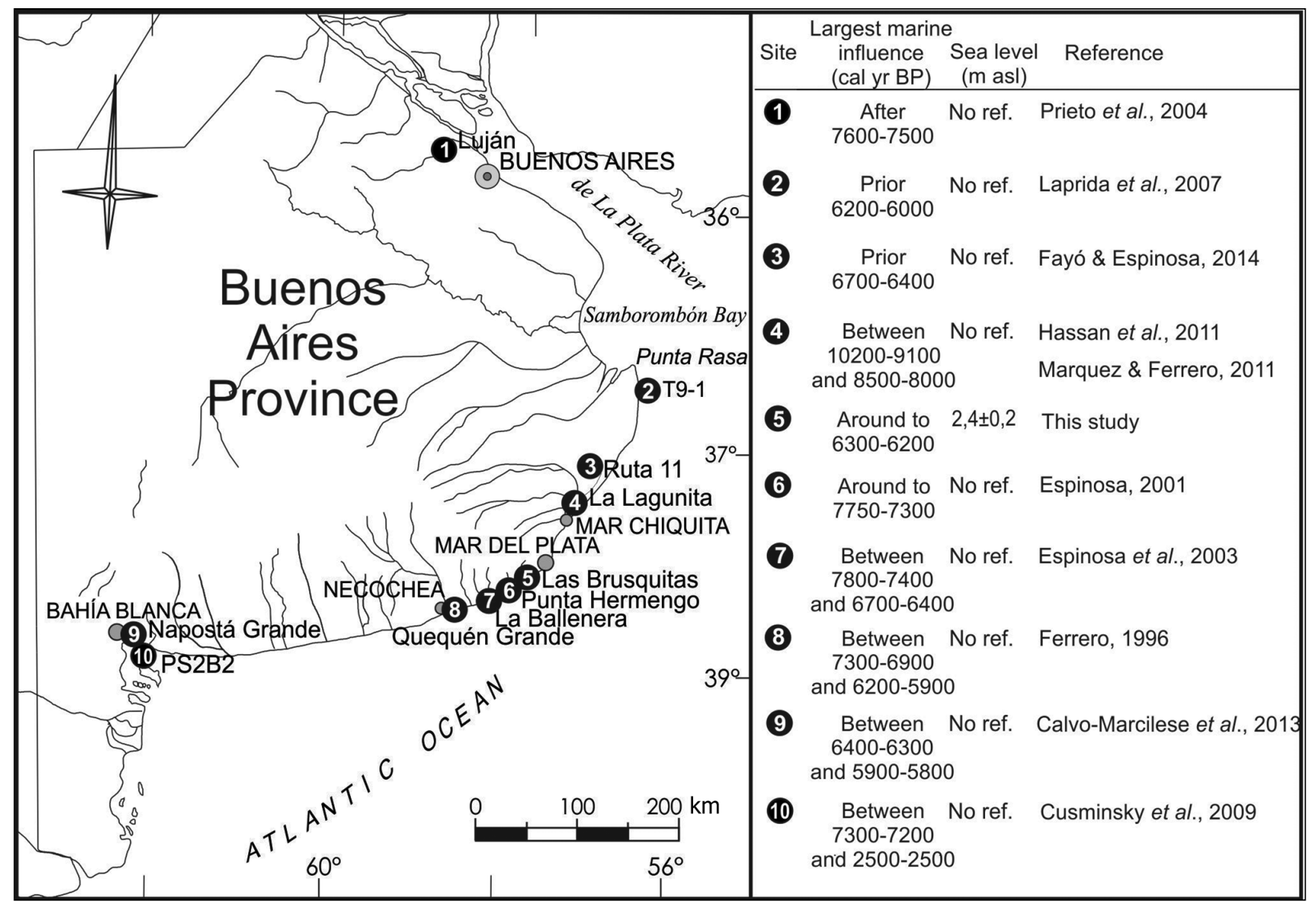

Figure 7. Location of sites discussed in the text of the Pampa coastal plain. 
of a non-marine environment. Around 6300-6200 cal yr BP marine influence rose and the environment changed to brackish-estuarine with moderate energy levels. Sometime before $c$. 6000-5700 cal yr BP sea-level drop giving rises to the development of clear-water lagoon, probably oligohaline, with abundant submerged vegetation. In a final stage (from 2300-2000 to 2000-1700 cal yr BP), a continental environment not influenced by the proximity of the sea was established.

The new chronologies provided by this work allowed adjusting two important events in the evolution of the Pampa coastal plain: firstly, the maximum transgressive to $6300-6200 \mathrm{cal}$ yr BP $\left(5400{ }^{14} \mathrm{C}\right)$ and secondarily a sporadic increase of marine connection to $4400-4200$ cal yr BP (c. $3900{ }^{14} \mathrm{C}$ yr BP).

This work, based on the combined study of foraminifera, ostracod and charophyte assemblages, is a new contribution to the understanding of paleoenvironmental evolution of marginal marine environments in the region. More data about Spirillina sp. A and its living conditions will be useful to improve the knowledge of these kinds of environments. The response of these group assemblages to environmental changes was shown to be very sensitive and complementary with other proxies.

\section{ACKNOWLEDGMENTS}

This study is a contribution to the projects PICT 20100082, PICT 2014-1271, PIP 00819, PIP 00021, EXA 587/12 and Comahue University Project B166. The results are part of the doctoral thesis of Melina Marquez. We thank A. Prieto and I. Vilanova for collaborating in the sampling and for providing us with useful information. We are grateful to both reviewers for their suggestions and comments which enriched this study.

\section{REFERENCES}

Aguirre, M.L. \& Whatley, R.C. 1995. Late Quaternary marginal marine deposits and paleoenvironments from northeastern Buenos Aires province: a review. Quaternary Science Reviews, 14:223-254. doi:10.1016/0277-3791(95)00009-E

Alperín, M.; Bernasconi, E. \& Cusminsky, G.C. 2008. Asociaciones de foraminíferos bentónicos actuales de la plataforma continental Argentina $\left(39^{\circ}-43^{\circ} \mathrm{S}\right.$ y $58^{\circ}-65^{\circ} \mathrm{O}$ ) analizados con métodos estadísticos para datos composicionales. Ameghiniana, 45:443-461.

Alve, E. \& Murray, J.W. 1999. Marginal marine environments of the Skagerrak and Kattegat: a baseline study of living (stained) benthic foraminiferal ecology. Palaeogeography, Palaeoclimatology, Palaeoecology, 146:171-193. doi:10.1016/ S0031-0182(98)00131-X

Apolinarska, K.; Pełechaty, M. \& Pukacz, A. 2011. $\mathrm{CaCO}_{3}$ sedimentation by modern charophytes (Characeae): can calcified remains and carbonate $\delta^{13} \mathrm{C}$ and $\delta^{18} \mathrm{O}$ record the ecological state of lakes? - a review. Studia Limnologica et Telmatologica, 5:55-66.

Bertels, A. \& Martínez, D.E. 1990. Quaternary ostracodes of continental and transitional littoral-shallow marine environments. Courier Forschungsinstitut Senckenberg, 123:141-159.

Bertels, A. \& Martínez, D.E. 1997. Ostrácodos holocenos de la desembocadura del arroyo Napostá Grande, sur de la provincia de Buenos Aires, Argentina. Revista Española de Micropaleontología, 29:29-69.

Berkeley, A.; Perry, C.T.; Smithers, S.G.; Horton, B.P. \& Taylor, K.G. 2007. A review of the ecological and taphonomic controls on foraminiferal assemblage development in intertidal environments. Earth-Science Reviews, 83:205-230. doi:10.1016/j.earscirev.2007.04.003

Berthold, W.U. 1976. Test morphology and morphogenesis in Patellina corrugata Willianson, Foraminiferida. Journal of Foraminiferal Research, 6:167-185. doi:10.2113/gsjfr.6.3.167

Boltovskoy, E. 1954a. Foraminíferos del golfo San Jorge. Revista del Instituto Nacional de Investigaciones y Museo Argentino de Ciencias Naturales Bernardino Rivadavia, Ciencias Geológicas, 3:85-246.

Boltovskoy, E. 1954b. Foraminíferos de la Bahía San Blas. Revista del Instituto Nacional de Investigaciones y Museo Argentino de Ciencias Naturales Bernardino Rivadavia, Ciencias Geológicas, 3:247-300.

Boltovskoy, E. 1957. Los foraminíferos del estuario del Río de La Plata y su zona de influencia. Revista del Instituto Nacional de Investigaciones y Museo de Ciencias Naturales Argentino Bernardino Rivadavia, Ciencias Geológicas, 6:1-77.

Boltovskoy, E. 1976. Distribution of recent foraminifera of the South American region. In: R.H. Hedley \& C.G. Adams (eds.) Foraminifera 2, Academic Press, p. 171-236.

Boltovskoy, E. \& Boltovskoy, A. 1968. Foraminíferos y Tecamebas de la parte inferior del río Quequén Grande (Prov. de Buenos Aires). Revista del Museo Argentino de Ciencias Naturales, Hidrobiología, 2:127-164.

Boltovskoy, E. \& Lena, H. 1974. Foraminíferos del Río de la Plata. Servicio de Hidrografía Naval, H661:1-22.

Boltovskoy, E.; Giussani, G., Watanabe, S. \& Wright, R. 1980. Atlas of benthic shelfforaminifera to the southwest Atlantic. New York, The Hague, 174 p. doi:10.1007/978-94-009-9188-0

Bonadonna, F.P.; Leone, G. \& Zanchetta, G. 1995. Composición isotópica de los fósiles de gasterópodos continentales de la provincia de Buenos Aires. Indicaciones paleoclimáticas. In: M.T. Alberdi; G. Leone \& E.P. Tonni (eds.) Evolución Biológica y Climática de la Región Pampeana durante los Últimos Cinco Millones de Años. Un Ensayo de Correlación con el Mediterráneo Occidental, Museo Nacional de Ciencias Naturales, Consejo Superior de Investigaciones Científicas, p. 78-104.

Brasier, M.D. 1975. Ecology of recent sediment dweling and phytal foraminifera from the lagoons of Barbuda, West Indies. Journal of Foraminiferal Research, 5:42-62. doi:10.2113/gsifr.5.1.42

Calvo-Marcilese, L. 2011. Sistemática y Paleoecología de los foraminifera (Protista) del Holoceno del área del estuario de Bahía Blanca, Argentina. Universidad Nacional de La Plata, Ph.D. thesis, $253 \mathrm{p}$.

Calvo-Marcilese, L. \& Langer, M. 2012. Ontogenetic morphogenesis and biogeographic patterns: resolving taxonomic incongruences within "species" of Buccella from South American coastal waters. Revista Brasileira de Paleontologia, 15:23-32. doi:10.4072/ rbp.2012.1.02

Calvo-Marcilese, L. \& Pratolongo, P. 2009. Foraminíferos de marismas y llanuras de marea del estuario de Bahía Blanca, Argentina: Distribución e implicaciones ambientales. Revista Española de Micropaleontología, 41:315-332.

Calvo-Marcilese, L.; Cusminsky, G. \& Gómez, E.A. 2011. Asociaciones de foraminíferos bentónicos en secciones holocenas del estuario de Bahía Blanca (Buenos Aires, Argentina). Ameghiniana, 48:210-225. doi:10.5710/amgh.v48i2(323)

Calvo-Marcilese, L.; Pérez Panera, J.P.; Cusminsky G \& Gómez EA. 2013. Micropaleontological record of Holocene estuarine 
stages in the Bahía Blanca estuary, Argentina. Journal of South American Earth Sciences, 45:147-159. doi:10.1016/j. jsames.2013.03.005

Cavallotto, J.L.; Violante, R.A. \& Parker, G. 2004. Sea-level fluctuations during the last $8600 \mathrm{yrs}$ in the de la Plata River, Argentina. Quaternary International, 114:155-65. doi:10.1016/ S1040-6182(03)00050-8

Closs, D. \& Madeira, M.L. 1968. Seasonal variations of brackish foraminifera in the Patos Lagoon, southern Brazil. Escola de Geologia, UFRGS, Porto Alegre, Publicação Especial, 15:1-51.

Cusminsky, G.C.; Bernasconi, E. \& Calvo-Marcilese L. 2009. Holocene benthic foraminifera from Bahía Blanca estuary: a review and update of systematic and palaeoenvironmental aspects. The Holocene, 19:1221-1231. doi: 10.1177/0959683609345085

Cusminsky, G.C.; Pérez, P.A.; Schwalb, A. \& Whatley, R. 2005. Recent lacustrine ostracods from Patagonia, Argentina. Revista Española de Micropaleontología, 37:431-450

Cusminsky, G.C.; Martínez, D. \& Bernasconi, E. 2006. Foraminíferos y ostrácodos de sedimentos recientes del estuario de Bahía Blanca, Argentina. Revista Española de Micropaleontología, 38:395-410.

D’Ambrosio, D.S. 2014. Reconstrucción Paleolimnológica de la Laguna Llancanelo (Mendoza, Argentina) a través del estudio de ostrácodos del Cuaternario. Universidad Nacional de La Plata, Ph.D. Thesis, 203 p.

de Rijk, S. \& Troelstra, S. 1999. The application of a foraminiferal actuo-facies model to salt-marsh cores. Palaeogeography, Palaeoclimatology, Palaeoecology, 149:59-66.

Debenay, J.-P.; Bénéteau, E.; Zhang, J.; Stouff, V.; Geslin, E.; Redois, F. \& Fernandez-Gonzalez, M. 1998. Ammonia beccarii and Ammonia tepida (Foraminifera): morphofunctional arguments for their distinction. Marine Micropaleontology, 34:235-244. doi:10.1016/S0031-0182(98)00192-8

Debenay, J.-P.; Geslin, E.; Eichler, B.B.; Duleba, W.; Sylvestre, F. \& Eichler, P. 2001. Foraminiferal assemblages in a hypersaline lagoon, Araruama (R.J.) Brazil. Journal of Foraminiferal Research, 31:133-151. doi:10.2113/0310133

Debenay, J.-P.; Guiral, D. \& Parra, M. 2004. Behaviour and taphonomic loss in foraminiferal assemblages of mangrove swamps of French Guiana. Marine Geology, 208:295-314. doi:10.1016/j.margeo.2004.04.013

Dias Brito, D.; Moura, J.A. \& Würdig, N. 1988. Relationships between ecological models based on ostracods and foraminifers from Sepetiba Bay (Rio de Janeiro, Brazil). In: T. Hanai, N. Ikeya \& K. Ishizaki (eds.) Evolutionary Biology on Ostracoda, Elsevier, p. 467-484. doi:10.1016/s0920-5446(08)70202-4

Diez, P.G.; Perillo, G.M.E. \& Piccolo, M.C. 2007. Vulnerability to Sea-Level Rise on the Coast of Buenos Aires Province. Journal of Coast Research, 23:119-126. doi:10.2112/04-0205.1

D’Antoni, H.L.; Nieto, M.A. \& Mancini, M.V. 1985. Pollen analytic stratigraphy of Arroyo Las Brusquitas profile (Buenos Aires province, Argentina). Zentralblatt fuer Geologie und Paläeontologie, 1:1721-1729.

Eichler, B.B.; Debenay, J,-P.; Bonetti, C. \& Duleba, W. 1995 Répartition des foraminifères benthiques dans la zone sudouest $\mathrm{du}$ système estuarien-lagunaire $\mathrm{d} \gg$ Iguape-Cananéia (Brésil). Boletim do Instituto Oceanográfico, 43:1-17. doi:10.1590/ s1679-87591995000100001

Espinosa, M.A. 2001. Reconstrucción de paleoambientes holocenos de la costa de Miramar (provincia de Buenos Aires, Argentina) basada en diatomeas. Ameghiniana, 38:27-34.

Espinosa, M.A.; Fasano, J.L.; Ferrero, L.; Isla, F.I.; Mujica, A. \& Schnack, E.J. 1984. Microestratigrafía y micropaleontología de los sedimentos holocenos aflorantes en la desembocadura del arroyo Las Brusquitas (Partido de General Pueyrredón) y en Punta Hermengo (Partido de General Alvarado), provincia de Buenos Aires. In: CONGRESO GEOLÓGICO ARGENTINO, 9, 1984. Actas III, San Carlos de Bariloche, p. 520-536.

Espinosa, M.; De Francesco, C.G. \& Isla, F.I. 2003. Palaeoenvironmental reconstruction of Holocene coastal deposits from the southeastern Buenos Aires Province, Argentina. Journal of Paleolimnology, 29:49-60.

Fasano, J.L. 1991. Geología y geomorfología, Región III: Faro Querandi-Mar de Cobo, Provincia de Buenos Aires. Report. Evaluación del Recurso Hídrico Subterráneo de la Región Costera Atlántica de la provincia de Buenos Aires, convenio de cooperación horizontal. CFI-UNMdP, 118 p.

Fasano, J.L.; Hernández, M.A.; Isla, F.I. \& Schnack, E.J. 1982. Aspectos evolutivos y ambientales de la laguna Mar Chiquita (provincia de Buenos Aires, Argentina). Oceanológica Acta, Número Especial, 285-292.

Fayó, R. \& Espinosa, M.A. 2014. Reconstrucción paleoambiental de la planicie costera de Mar Chiquita (provincia de Buenos Aires, Argentina) durante el Holoceno, basada en diatomeas. Ameghiniana, 51:510-528. doi:10.5710/AMGH.13.10.2014.2812

Ferrero, L. 1996. Paleoecología de ostrácodos holocenos del estuario del río Quequén Grande (provincia de Buenos Aires). Ameghiniana, 33:209-222.

Ferrero, L. 2006. Micropaleontología y Paleoecología del Cuaternario del sudeste de la provincia de Buenos Aires. Universidad Nacional de Mar del Plata, Ph.D. Thesis, 371 p.

Ferrero L. 2009. Foraminíferos y ostrácodos del Pleistoceno tardío (Mar Chiquita, provincia de Buenos Aires, Argentina). Ameghiniana, 46:637-656.

Fontana, S.L. 2004. Present and Past Coastal Dune Environments of South Buenos Aires Province, Argentina. Acta Universitatis Upsaliensis. Comprehensive Summaries of Uppsala Dissertations from the Faculty of Science and Technology 940, 38 p.

García, A. 1994. Charophyta: their use in paleolimnology. Journal of Paleolimnology, 10:43-52. doi:10.1007/bf00683145

Goldstein, S.T. \& Watkins, G.D. 1999. Taphonomy of salt marsh foraminifera: an example from coastal Georgia. Palaeogeography, Palaeoclimatology, Palaeoecology, 149:103-114. doi:10.1016/ S0031-0182(98)00195-3

Gómez, E.A. \& Perillo, G.M.E. 1995. Submarine outcrops underneath shoreface- connected sand ridges, outer Bahía Blanca Estuary, Argentina. Quaternary of South America and Antarctic Peninsula, 9:23-37.

Gómez, E.A.; Martínez, D.E.; Borel, C.M.; Guerstein, G.R. \& Cusminsky, G.C. 2005. Submarine evidences of Holocene sealevel fluctuations in the Bahia Blanca estuary, Argentina. Journal of South American Earth Sciences, 20:139-155. doi:10.1016/j. jsames.2005.06.011

Gómez, E.A.; Martínez, D.E.; Borel, C.M.; Guerstein, G.R. \& Cusminsky, G.C. 2006. Negative sea-level oscillation at the Bahía Blanca estuary related to a ca. 2650 yr BP global climatic change. Journal of Coastal Research, Special Issue, 39:181-85.

Gómez, E.A.; Borel, C.M.; Aguirre, M. \& Martínez, D.E. 2008. Radiocarbon reservoir ages and hardwater effect for the northeastern coastal waters of Argentina. Radiocarbon, 50:119-129.

González, M.A. 1984. Depósitos marinos del Pleistoceno superior en Bahía Blanca, Provincia de Buenos Aires. In: CONGRESO GEOLÓGICO ARGENTINO, 9, 1984. Actas III, San Carlos de Bariloche, 538-555 p. 
González, M.A. 1989. Holocene levels in the Bahía Blanca Estuary, Argentina Republic. Journal of Coastal Research, 5:65-77.

Grimm, E.C. 1991. Tilia Software. Illinois State Museum. Research and Collection Center. Springfield, Illinois.

Hartmann, G., 1962. Zur Kenntnis des Eulitorals der Chiilenischen Pazifikkuste und der argentinischen Kuste Sudpatagoniens unter besonderer Berucksichtigung der Polychaeten und Ostracoden, Teil III.- Mitteilungen Hamburger Zoologisches Museum Institut, 60:169-270.

Hassan, G.; Espinosa, M.A. \& Isla, F.I. 2011. Fluctuaciones holocenas de salinidad en la laguna costera Mar Chiquita (provincia de Buenos Aires, Argentina): una aproximación cuantitativa basada en diatomeas. Ameghiniana, 48:496-507.

Hayward, B.W.; Grenfell, H.; Nicholson, K.; Parker, R.; Wilmhurst, J.; Horrocks, M.; Swales, A. \& Sabaa, A.T. 2004. Foraminiferal record of human impact on intertidal estuarine environments in New Zealand's largest city. Marine Micropaleontology, 53:37-66. doi:10.1016/j.marmicro.2004.03.001

Hayward, B.W. 2014. "Monospecific" and near-monospecific benthic foraminiferal faunas, New Zealand. Journal of Foraminiferal Research, 44:300-315. doi:10.2113/gsjfr.44.3.300

Hogg, A.G.; Hua, Q.; Blackell, P.G.; Niu, M.; Buck, C.E.; Guilderson, T.P.; Heaton, T.J.; Palmer, J.G.; Reimer, P.J.; Reimer, R.W.; Turnery, C.S.M. \& Zimmerman, S.R.H. 2013. SHCal13 Southern Hemisfere calibration, 0-50000 years cal BP. Radiocarbon, 55:1889-1903. doi:10.2458/azu_js_rc.55.16783

Hromic, T.; Andrade, C.; Ramírez, I. \& Vidal, S. 2004. Nuevo Registro de Spirillina tuberculata Brady (Protozoa: Foraminiferida) en Aguas Chilenas. Anales del Instituto de la Patagonia, 32:35-41.

Isla, F.I. 1989. Holocene sea level fluctuation in the southern hemisphere. Quaternary Science Reviews, 8:359-368. doi:10.1016/0277-3791(89)90036-X

Isla, F.I. \& Espinosa, M.A. 1998. Modelo sedimentario de colmatación de pequeños estuarios dominados por limo, provincia de Buenos Aires. In: REUNIÓN ARGENTINA DE SEDIMENTOLOGÍA, 7, 1998. Actas, Salta, 24-36 p.

Isla, F.I.; Fasano, M.A; Ferrero, L.; Espinosa, M. \& Schnack, E.J. 1986. Late Quaternary marine-estuarine sequences of the southeastern coast of the Buenos Aires Province, Argentina. Quaternary of South America and Antarctic Peninsula, 4:137-157.

Isla, F.I; Cortizo, L.C. \& Schnack, E.J. 1996. Pleistocene and Holocene beaches and estuaries along the Southern barrier of Buenos Aires, Argentina. Quaternary Science Reviews, 15:833-841. doi:10.1016/S0277-3791(96)00065-0

Külköylüoĝlu, O. 2003. Ecology of freshwater Ostracoda (Crustacea) from lakes and reservoirs in Bolu, Turkey. Journal of Freshwater Ecology, 18:343-347. doi:10.1080/02705060.2003.9663968

Külköylüoğlu, O. \& Vinyrad, G.L. 2000. Distribution and ecology of freshwater Ostracoda (Crustacea) collected from springs of Nevada, Idaho, and Oregon: a preliminary study. Western North American Naturalist 60:291-303.

Laprida, C. 2006. Ostrácodos recientes de la llanura pampeana, Buenos Aires, Argentina: ecología e implicancias paleolimnológicas. Ameghiniana, 43:181-204.

Laprida, C. \& Bertels-Psotka, A. 2003. Benthic foraminifers and paleoecology of a Holocene shelly concentration, Salado Basin, Argentina. Geobios, 36:559-572. doi:10.1016/S00166995(03)00061-5

Laprida, C.; García-Chapori, N.; Violante, R.A. \& Compagnucci, R.H. 2007. Mid-Holocene evolution and paleoenvironments of the shoreface-offshore transition, north-eastern Argentina:
New evidence based on benthic microfauna. Marine Geology, 240:43-56. doi:10.1016/j.margeo.2007.02.001

Laprida, C.; Plastani, M.S.; Irurzún, A.; Gogorza, C.; Navas, A.M.; Valero-Garcés, B. \& Sinito, A.M. 2014. Mid-late Holoecene lake levels and trophic states of a shallow lake from the southern Pampa plain, Argentina. Journal of Limnology, 73:325-339. doi:10.4081/jlimnol.2014.830

Lee, R.E. 2008. Phycology. New York, Cambridge University Press, $547 \mathrm{p}$.

Lena, H. \& L'Hoste, S. 1975. Foraminíferos de aguas salobres (Mar Chiquita, Argentina). Revista Española de Micropaleontología, 7:539-48.

Loeblich, A.R. \& Tappan, H. 1988. Foraminiferal genera and their classification, Vol.1. New York, Van Nostrand Reinhold Company, $970 \mathrm{p}$.

Marquez, M. \& Ferrero, L. 2011. Paleoecología de foraminíferos de un testigo holoceno en la planicie costera de la laguna Mar Chiquita, Buenos aires, Argentina. Ameghiniana, 48:289-304. doi:10.5710/AMGH.v48i3(338)

Marquez, M., Ferrero; L. \& Cusminsky, G.C. 2013. Distribución superficial de foraminíferos bentónicos en ambientes litorales del sudeste de la provincia de Buenos Aires, Argentina: una aplicación de análogos modernos en estudios paleoambientales. In: REUNIÓN ANUAL DE COMUNICACIONES DE LA ASOCIACIÓN PALEONTOLÓGICAARGENTINA, 2013. Suplemento Resúmenes, Córdoba, Ameghiniana, $31 \mathrm{R}$.

Martínez, D. E. 2005. Asociaciones de ostrácodos modernos del estuario de Bahía Blanca, Buenos Aires, Argentina. Ameghiniana, 42:669-684.

Meisch, C. 2000. Freshwater Ostracoda of Western and Central Europe. Berlin, Spektrum Academischer, $522 \mathrm{p}$.

Murray, J.W. 2006. Ecology and applications of benthic foraminifera. New York, Cambridge University Press, 426 p.

Ornellas, L.P. \& Würdig, N. 1983. Cyprideis salebrosa hartmanni Ramírez, 1967, a new subespecies from Brasil and Argentina. Pesquisas, 15:94-112.

Pawlowski, J.; Bolivar, I.; Fahrni, J. \& Zaninetti, L. 1995. DNA analysis of "Ammonia beccarii" morphotypes: one or more species? Marine Micropaleontology, 26:171-178. doi:10.1016/0377-8398(95)00022-4

Prieto, A.R.; Vilanova, I. \& De Francesco, C.G. 2003. Estratigrafía y paleoecología del Pleistoceno Tardío-Holoceno del área del arroyo Las Brusquitas, Buenos Aires, Argentina: una revisión. In: M.M. Collantes; J.M. Sayago; L. del V. Neder (eds.). Cuaternario y Geomorfología, Actas, p. 147-156.

Prieto, A.R.; Blasi, A.M.; De Franceso, G.C. \& Fernández, C. 2004. Environmental history since $11,000{ }^{14} \mathrm{C}$ yr B.P. of the northeastern Pampas, Argentina, from alluvial sequences of the Luján River. Quaternary Research, 62:146-161. doi:10.1016/j.yqres.2004.04.006

Ramírez, F.C. 1967. Ostrácodos de lagunas de la provincia de Buenos Aires. Revista del Museo de La Plata (nueva serie), Zool., 10:5-54.

Ramón-Mercau, J.; Plastani, M.S. \& Laprida, C. 2014. A review of the genus Limnocythere (Podocopida: Limnocytheridae) in the Pampean region (Argentina), with the description of a new species, Limnocythere cusminskyae sp. nov. Zootaxa, 3821:026-036. doi:10.11646/zootaxa.3821.1.2

Reolid, M.; Rodríguez-Tovar, F.J; Nagy, J. \& Olóriz, F. 2008. Benthic foraminiferal morphogroups of mid to outer shelf environments of the Late Jurassic (Prebetic Zone, southern Spain): Characterization of biofacies and environmental significance. Palaeogeography, Palaeoclimatology, Palaeoecology, 261:280-299. doi:10.1016/j. palaeo.2008.01.021 
Ritter, M.N. \& Erthal, F. 2011. Zona tafonomicamente ativa em ambiente estuarino lagunar com base em moluscos da planície costeira do Rio Grande do Sul, Brasil. In: I.S. Carvalho; N.K. Srivastava; O. Strohschoen Jr. \& C.C. Lana (orgs.) Paleontologia: Cenários de Vida, Interciência, p. 355-365.

Schnack, E.J., Fasano, J.L. \& Isla, F.I. 1982. The evolution of Mar Chiquita lagoon coast, Buenos Aires Province, Argentina. In: D.J. Colquhoun (ed.) Holocene sea level fluctuations: magnitude and causes, INQUA, p. 143-155.

Schnack, E.J.; Isla, F.I.; De Francesco, F.O. \& Fucks, E.E. 2005. Estratigrafía del Cuaternario marino tardío en la provincia de Buenos Aires. In: R.E. de Barrio; R.O. Etcheverry; M.F. Caballé \& E. Llambías (eds.) Geología y Recursos Minerales de la Provincia de Buenos Aires. Relatorio del $16^{\circ}$ Congreso Geológico Argentino (La Plata), p. 159-182.

Schnitker, D. 1974. Ecotypic variation in Ammonia beccarii (Linné). Journal of Foraminiferal Research, 4:216-223. doi:10.2113/ gsjfr.4.4.217

Scott, D.B.; Schnack, E.J.; Ferrero, L.; Espinosa, M. \& Barbosa, C.F. 1990. Recent marsh foraminifera from the east coast of South America: comparison to the Northern hemisphere. In: C. Hemleben; M.A. Kaminski; W. Kuhn \& D.B. Scott (eds.) Paleoecology, Biostratigraphy, Paleoceanography and Taxonomy off Agglutinated Foraminifera, Kluwer Academic Publishers, p.717-737.

Sen Gupta, B.K. 1999. Foraminifera in marginal marine environments. In: B.K. Sen Gupta (ed.) Modern Foraminifera, Kluwer Academic Publishers, p. 141-159. doi:10.1007/0-306-48104-9_9

Stuiver, M.; Reimer, P.J. \& Reimer, R.W. 1986. Calib 7.0.2. World Wide Web: http://calib. qub.ac.uk/calib/

Stutz, S.; Prieto, A.R. \& Isla, F.I.1999. Cambios de vegetación durante el Holoceno en el SE de la provincia de Buenos Aires análisis polínico del arroyo La Ballenera. In: Asociación Paleontológica Argentina, Special publication no. 6, Asociación Paleontológica Argentina, p. 65-69.

Stutz, S.; Prieto, A.R. \& Isla, F.I 2005. Holocene evolution of the Mar Chiquita lagoon area (Argentina) indicated by pollen analysis. Journal of Quaternary Science, 20:1-12.

Tonni, E.P.; Cione, A.L.; Landoni, N. \& Figini, A.J. 1999. A small Holocene deposit of marine brackish origin on the southeastern coast of the Pampean region of Argentina. Current Research in the Pleistocene, 17:147-149.
Vilanova, I.; Prieto, A.R. \& Espinosa, M. 2006. Palaeoenvironmental evolution and sea-level fluctuations along the southeastern Pampa grasslands coast of Argentina during the Holocene. Journal of Quaternary Science, 21:227-242. doi:10.1002/jqs.953

Violante, R.A. 1992. Ambientes sedimentarios asociados a un sistema de barrera litoral del Holoceno en la llanura costera al sur de Villa Gessell, provincia de Buenos Aires. Revista de la Asociación Geológica Argentina, 47:201-214.

Violante, R.A. \& Parker, G. 1992. Estratigrafía y rasgos evolutivos del Pleistoceno medio a superior-Holoceno en la llanura costera de la región de Faro Querandí (provincia de Buenos Aires). Revista de la Asociación Geológica Argentina, 47:215-227.

Violante, R.A. \& Parker, G. 2004. The post-last glacial maximum transgression in the de la Plata River an adjacent inner continental shelf, Argentina. Quaternary International, 114:167-81. doi:10.1016/S1040-6182(03)00036-3

Violante, R.A. \& Cavalloto, J.L. 2004. Evolution of the semienclosed basins and surrounding coastal plains adjacent to the Pampean Region, Argentina. Polish Geological Institute Special Papers, 11:59-70.

Violante, A.; Parker, G. \& Cavallotto, L. 2001. Evolución de las llanuras costeras del este bonaerense entre la Bahía Samborombón y la laguna Mar Chiquita durante el Holoceno. Revista de la Asociación Geológica Argentina, 56:51-66.

Walton, W.R. \& Sloan, B.J. 1990. The genus Ammonia Brunnich, 1772: Its geographic distribution and morphologic variability. Journal of Foraminiferal Research, 20:128-156. doi:10.2113/gsjfr.20.2.128

Wang, P. \& Lutze, G.F. 1986. Inflated later chambers: Ontogenetic changes of some Recent hyaline benthic foraminifera. Journal of Foraminiferal Research, 16:48-62. doi:10.2113/gsjfr.16.1.48

Whatley, R.C.; Moguilevsky, A.; Chadwick, J.M.; Toy, N. \& Ramos, M.I.F. 1998. Ostracoda from the South West Atlantic. Part III. The Argentinean, Uruguayan and Southern Brazilian Continental Shelf. Revista Española de Micropaleontología, 30:89-116.

Whatley, R.C.; Toy, N.; Chadwick, J.M. \& Ramos, M.I.F. 1997. Ostracoda from the South West Atlantic. Part II. The littoral fauna from between Tierra del Fuego and the Río de la Plata. Revista Española de Micropaleontología, 29:5-83.

Received in October, 2015; accepted in March, 2016. 
Appendix 1. Faunal reference list.

Faunal reference list

Class Foraminiferida Loeblich y Tappan (1992)

Cornuspira planorbis Schultze, 1854

Miliolinella subrotunda (Montagu, 1803) = Vermiculum subrotundum Montagu, 1803

Spirillina sp. A

Bolivina sp.

Haynesina depressula (Walker \& Jacob, 1798) = Nautilus depressulus Walker and Jacob, 1798

Nonion pauperatum (Balkwill \& Wright, 1885) = Nonionina pauperata Balkwill y Wright, 1885

Nonion sp.

Nonionella sp.

Buccella peruviana (d'Orbigny, 1839) = Rotalina peruviana d'Orbigny, 1839

Ammonia parkinsoniana (d'Orbigny, 1839) = Rosalina parkinsoniana d'Orbigny, 1839

Ammonia tepida Cushman, 1926

Cribroelphidium excavatum (Terquem, 1875) = Polystomella excavata Terquem, 1875

Cribroelphidium poeyanum (d'Orbigny, 1826) = Polystomella poeyana d'Orbigny, 1826

Elphidium gunteri Cole, 1931

Elphidium margaritaceum Cushman, 1930

Elphidium sp.

Class Ostracoda Latreille, 1806

Chlamydotheca incisa (Claus, 1893) = Pachycypris incisa Claus, 1892

Heterocypris incongruens $($ Ramdohr, 1808) = Cypris incongruens Ramdohr, 1808

Cypridopsis vidua (O. F. Müller, 1776) = Cypris vidua Müller, 1776

Sarscypridopsis aculeata $($ Costa, 1847) = Cypridopsis aculeata Costa, 1847

Potamocypris sp.

Candona sp.

Darwinula? sp.

Cyprideis multidentata Hartmann, 1955

Cyprideis salebrosa Bold, 1963

Parakrithella hanai Hartmann, 1962

Cytherura dimorphica Bertels \& Martínez, 1997

Leptocythere sp.

Callistocythere litoralensis (Rossi de García, 1966) = Perissocytheridea litoralensis Rossi de García, 1966

Limnocythere multiperforata (Whatley \& Cholich, 1974) = Pampacythere multiperforata Whatley \& Cholich, 1974

Limnocythere solum (Whatley \& Cholich, 1974) = Pampacythere solum Whatley \& Cholich, 1974

Limnocythere cusminskyae Ramón-Mercau, Plastani \& Laprida, 2014

Limnocytheridae gen. et sp. indet.

Pellucistoma elongata Whatley, Moguilevsky, Toy, Chadwick \& Ramos, 1997

Xestoleberis sp. 